\title{
FOD Experimental Simulation and Analysis of Potential Benefits of Modified Blisk Geometry
}

\section{Libor Beránek, Zdeněk Pitrmuc, Jan Šimota}

Department of Machining, Process Planning and Metrology, Faculty of Mechanical Engineering, Czech Technical University in Prague. E-mail: libor.beranek@fs.cvut.cz, zdenek.pitrmuc@fs.cvut.cz, jan.simota@fs.cvut.cz

The article deals with testing of the resistance against Foreign Object Damage (FOD) on leading edges of blisks (blade disks) in turboprop engines made of Ti6Al4V alloy. Such damage can occur during operation, when rapidly rotating compressor parts on the engine intake are exposed to foreign particles. E.g. operation of small passenger aircrafts in desert areas, where large amounts of foreign particles occurs in the atmosphere. The paper describes the development of method for testing the resistance of the leading edge of the blades against FOD in order to mimic the conditions of operational damage. Further it quantifies potential benefits of modification in the geometry of the blisk leading edge and compares results of FOD resistance of sharp leading edge and modified geometry. Results of metallographic analysis for deformed areas near the FOD on Ti6Al4V alloy are also presented.

Keywords: FOD, Foreign Object Damage, Ti6Al4V blisk

\section{Acknowledgement}

This work was supported by the Technological Agency of Czech Republic-project number TH01011405.

\section{References}

[1] MRAZ, S., BRAND, M. (2000). BLISKS GIVE ENGINES MORE PUNCH. Machine Design. 72, 13, 62, July 6, 2000. ISSN: 00249114.

[2] SMOLÍK, L., RENDLOVÁ, Z., BYRTUS, M. (2015). An Analysis of the Influence of the Titanium Compressor Wheel on the Dynamical Properties of the Particular Turbocharger Rotor In: Manufacturing Technology, Vol.15, pp. 93-99. 1213-2489.

[3] LATTNER, R., HOLEŠOVSKÝ, F., KAREL, T., LATTNER, M. (2015). Abrasive Machining of Ti6Al4V Alloy, In: Manufacturing technology, Vol. 15, September, No. 4, ISSN 1213-2489.

[4] PETUKHOV, A. N. (2005) High-Cycle Fatigue of Materials and Parts of Gas-Turbine Engines. In: Strength of Materials, 05/2005, Year 37.

[5] KOZLOV, L. A., BALASHOV, B. F. (1983). Probability estimates of fatigue strength and stresses acting in machine parts in connection with the strength analysis under high-cycle loading. Probl. Prochn., No. 5, 59-64 (1983)

[6] RUSCHAU, J. J., NICHOLAS, T., THOMPSON, S. R. (2001). Influence of foreign object damage (FOD) on the fatigue life of simulated Ti-6Al-4V airfoils. International Journal of Impact Engineering [online]. 2001, 25(3), 233-250 [cit. 2017-03-27]. DOI: 10.1016/S0734-743X(00)00044-0. ISSN 0734743x

[7] THOMPSON, S. R., RUSCHAU, J. J., NICHOLAS, T. (2001). Influence of residual stresses on high cycle fatigue strength of Ti-6Al-4V subjected to foreign object damage. International Journal of Fatigue [online]. 2001, 23, 405-412 [cit. 2017-03-27]. DOI: 10.1016/S0142-1123(01)00166-9. ISSN 01421123.

[8] MALL, S., HAMRICK, J. L., NICHOLAS, T. (2001). High cycle fatigue behavior of Ti-6Al-4V with simulated foreign object damage. Mechanics of Materials [online]. 2001, 33(11), 679-692 [cit. 2017-03-27]. DOI: 10.1016/S0167-6636(01)00084-9. ISSN 01676636.

[9] CHEN, Xi. (2005). Foreign object damage on the leading edge of a thin blade. Mechanics of Materials [online]. 2005, 37(4), 447-457 [cit. 2017-03-27]. DOI: 10.1016/j.mechmat.2004.03.005. ISSN 01676636. 